\title{
Effect of flexible soil in seismic hazard assessment for structural design in Kuala Lumpur
}

\begin{abstract}
Kuala Lumpur, Malaysia, is considered to be safe against an earthquake threat. However, tremors felt by occupants due to long distance earthquakes from Sumatra has raised concern on building safety in this region. Consequently, Malaysia will adopt the Eurocode 8 for seismic design. The suitability of this code must be studied especially on the threat from far field earthquakes. Thus, site specific hazard assessment has been conducted on seven flexible soil sites in Kuala Lumpur, based on modified time history. The peak ground acceleration (PGA) falls in the category of very low seismicity, however, the amplifications are much higher than recommended by Eurocode 8 . The period limits for maximum accelerations are also much higher compared to the value in the code, especially for flexible soils. Adoption of Eurocode 8 for seismic design in this region should be studied to include the effects of high period motions in flexible soils, especially on the amplification factors and its corner periods.
\end{abstract}

Keyword: Eurocode 8; Far field earthquake; Ground response analysis; Response spectrum; Seismic; Site response; Soil amplification 